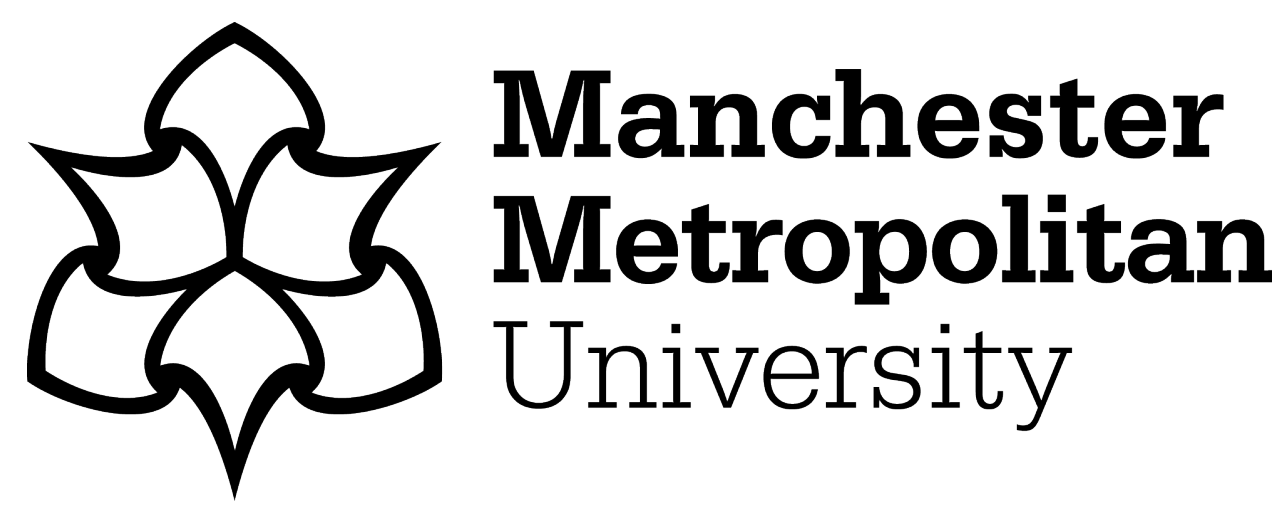

Hulme, Moira ORCID logoORCID: https://orcid.org/0000-0002-4095-3880, Beauchamp, Gary and Clarke, Linda (2020) Doing advisory work: the role of expert advisers in national reviews of teacher education. Journal of Further and Higher Education, 44 (4). pp. 498-512. ISSN 0309-877X

Downloaded from: https://e-space.mmu.ac.uk/622433/

Version: Accepted Version

Publisher: Taylor \& Francis (Routledge)

DOI: https://doi.org/10.1080/0309877X.2019.1580687

Please cite the published version 


\title{
Doing advisory work: the role of expert advisers in national reviews of teacher education.
}

\author{
Moira Hulme', Gary Beauchamp ${ }^{2}$, Linda Clarke ${ }^{3}$ \\ ${ }^{1}$ Manchester Metropolitan University; ${ }^{2}$ Cardiff Metropolitan University; ${ }^{3}$ Ulster \\ University, $U K$.
}

Corresponding author: Professor Moira Hulme, Faculty of Education, Manchester Metropolitan University, 53 Bonsall Street, Manchester, M15 6GX. Email:

m.hulme@mmu.ac.uk Mob: 07896896258. Orcid.org/0000-0002-4095-3880

Biographical notes:

Moira Hulme is Professor of Teacher Education at Manchester Metropolitan University.

Gary Beauchamp is Professor of Education and Associate Dean Research at the Cardiff School of Education and Social Policy, Cardiff Metropolitan University.

Linda Clarke is Professor of Education and Director of Research at the School of Education, Ulster University. 


\section{Doing advisory work: the role of expert advisers in national reviews of teacher education.}

The role and activities of national advisers engaged in the translation of globally mobile ideas on effective teacher education has received little attention. Drawing on in-depth semi-structured interviews, this article explores how government appointed advisers acted as intermediaries in the translation of policy ideas in national reviews of teacher education in Scotland, Wales and Northern Ireland (2010-2015). Three themes are addressed: (1) the localisation of international good practice; (2) the significance of time and temporality in local policy deliberation; and (3) the autonomy-engagement dynamic in government commissioned reviews of public policy fields. The article reports how advisers exhibited transgressive competence in the re-assembly of policy ideas in local spaces. With attention to time, space and positionality, the article concludes by emphasising the significance of localised political strategies in shaping policy choices and prospects for enactment.

Keywords: teacher education; educational policy; United Kingdom.

\section{Introduction}

While there is a growing body of work directed at how policy moves (Seddon and Levin, 2013; Clarke et al., 2015), little attention has been paid to the role of expert advisers engaged in the translation of globally mobile ideas within national and subnational government contexts (Lingard et al., 2015). The emergence of a 'global education policy field' (Lingard and Rawolle 2011, 489) has, in important respects, relocated political authority beyond the national state. Transnational policy actors are increasingly influential in directing the flow of policy ideas in teacher education (European Commission, 2015; OECD, 2011; World Bank, 2013). Through the use of soft governance mechanisms (peer review processes, indices of quality and transnational benchmarks) international organisations act as 'entrepreneurs of convergence' reducing the range of options considered by national policy makers

(Martens et al. 2010, 18). We argue here that while international organisations privilege 
some policy options over others, context remains important. Travelling ideas are subject to translation as they are put to work within local projects. We employ Clarke et al.'s $(2015,35)$ definition of translation as, 'a selective and active process in which meanings are interpreted and reinterpreted to make them fit their new context'. Following McCann and Ward $(2013,5)$, our attention is directed towards 'who constructs and interconnects scales and how do they do it'. Specifically we consider how advisers, as knowledge actors who are positioned and who take up positions in contractual relations, engage in the social practices of consultation.

Between 2010 and 2015 four reviews of the national arrangements for teacher education were conducted by the three devolved Governments of the UK (Donaldson 2011; Sahlberg et al., 2012; Taberrer, 2013; Furlong, 2015). In each jurisdiction, the review considered the case for change and presented options for change for policymakers. It is not our intention to outline the content of these public reports, or to elaborate on the detail of subsequent (short-term) policy outcomes; this has received attention elsewhere (Teacher Education Group, 2016; Kennedy and Doherty, 2012). The focus here is on advisory work as social practice. The aim of this study was to understand more clearly how advisers act as mediators in the translation of policy alternatives in particular contexts, and the conditions that permit or preclude certain possibilities. Drawing on an 'assemblage perspective' (Prince 2010, 169), this article explores how commissioned experts acted as intermediaries in the translation and reterritorialisation of policy ideas. In making sense of deliberation on policy alternatives, we foreground agency and use the concept of assemblage to describe how policy options are constantly in formation. We apply the distinction made by Collier and Ong $(2005,12)$, who suggest that 'global implies broadly encompassing, seamless and mobile; [whereas] assemblage implies heterogeneous, contingent, unstable, partial and 
situated.' Through an applied case, this small-scale study aims to deepen our understanding of the 'travelling/embedded' (Alexiadou and Jones, 2001), 'mobilities/moorings' dialectic in policy research (Urry, 2003). This is achieved by addressing practices of assembly in one policy field, with attention to spatial and temporal dimensions. In doing so, we address an omission in education policy studies.

The United Kingdom in the post-devolution period presents an interesting opportunity to examine how, and how far, policy ideas move across geographical borders and organisational boundaries in a closely linked system. Studies that record the UK as a key exporter of neo-liberal experimentation in education policy often fail to disaggregate the four constituent nations of the UK. Significant differences in the politics and processes of policy formation have been identified in cross-UK or 'home international' studies (Beauchamp et al. 2015; Hodgson and Spours, 2016). The considerable entanglements of multi-level government presented by devolution in the UK are helpful in resisting 'methodological nationalism' (Beck, 2006), that is not privileging the nation-state as the 'container' of policy moves by drawing attention to 'tangled scalar relations' (Peck 2002, 331) and the achievement of temporary policy settlements. By examining the contribution of advisory work to 'policy assemblages, mobilities and mutations' (McCann and Ward, 2012) the study has relevance beyond the national scale. In attending closely to the re-contextualisation of policy ideas as they enter policy communities with distinctive traditions, we aim to avoid a tendency towards 'historical amnesia' among studies of policymaking (Clarke, 2012). Moreover, in directing attention to the politics of education, this study rejects the long-standing 'peripheralisation' of three of the four home nations in policy debate in the UK (Lovering, 1991). 
The structure of systems for scientific advice (provided through Advisory Councils, Advisory Committees, National Academies, learned societies and networks, Chief Scientific Advisers) have been subject to debate at national, European and global levels (Wilsdon and Doubleday, 2015). The role of expert advisors in the European Union has attracted intense critical attention in response to a perceived 'democratic deficit' and concomitant agencification (Ambrus et al., 2014). Critical commentaries have remarked negatively on the rise of 'consultocracy' (Gunter et al., 2014) or 'expertocracy' (Grek, 2013). Scrutiny of UK government consultant assignments increased from 2010 (Craft and Howlett, 2012; NAO, 2016). By comparison, the role of government-appointed experts in decision-making at sub-state and regional levels is neglected, especially in areas of policy choice that cannot be simply data-driven. Whilst teacher education policy has become deeply politicised in the last decade, teacher education politics have proven resilient to the degree of scientisation experienced in other fields of public policy (Jung et al., 2014; Goldhaber, 2018). There are few claims to evidence-based policy in teacher education (Cochran-Smith et al., 2016). Reasons for this may include data deficiencies, a relatively weak and emerging epistemic community in regard to evidence-based intervention and policy evaluation, combined with limited and contracting funding opportunities for large-scale longitudinal studies, and the persistence of strongly framed professional boundaries among influential veto players. In the context of teacher education policy, potential veto players include Teaching Councils, teacher unions, local authorities and providers of faith-based education.

To explore these issues further this article reports elite interviews with six key government-appointed experts, who have been advisers in government commissioned reviews of teacher education policy in Scotland, Wales and Northern Ireland, 
contextualised by professional biographies including network links, and documentary analysis. This leads to an account of how an identified set of de-contextualised policy ideas about 'world class teacher education' was re-contextualised and subject to social contestation in specific policy locales. Our attention is focused on government appointed advisors as knowledge brokers and 'conduits of policy mobility' (Ball 2016, 557). In attending to contextual differences and the local dynamics of change, we acknowledge that while official reviews are commissioned to address policy problems, policy 'immobilities' (McCann, 2008) may also be achieved as an outcome of contestation.

The article is organised in four sections. First, we examine the context for advisory work, namely policy divergence in the UK as a consequence of democratic devolution. Theoretical perspectives on expertise are also included in this section. The second section outlines the methodological approach used in conducting adviser interviews. The third section presents three key themes from the analysis of interviewees' accounts of advisory practice, with reference to review outputs. The article concludes by positioning policy advice as one factor contributing to a process of open-ended or 'restless reform' (Peck 2002, 331) rather than a key variable in securing evidence-based policy.

\section{Political devolution and policy divergence}

Devolution, as an evolving and uneven process of constitutional change, creates new spaces for deliberation on alternatives within an increasingly globalised policy field. Formal devolution of legislative powers from Westminster followed referenda in Scotland and Wales in 1997, and Northern Ireland in 1998. Party political incongruence is now a feature of UK government. No single political party has held overall power in more than one of the four UK nations from 2010. Responsibility for policy related to 
teacher development resides with the Department for Education in England, the Scottish Government (Riaghaltas na h-Alba) at Holyrood Edinburgh, the Welsh Government (Llywodraeth Cymru) at Cardiff, and the Northern Irish Executive at Stormont. There are significant differences in terms of the scale and structure of provision (Davies et al., 2016). The devolved administrations retain control over modes of teacher preparation (permissible routes to qualification, entry requirements, partnership with schools and quality assurance), allocation of student places to providers (almost exclusively universities and university colleges, with the exception of Teach First Cymru introduced in 2013) and teacher supply. Different sets of statutory Teachers' Standards or competences exist in Scotland, Wales, Northern Ireland and England. Cross-border teacher mobility within the UK is affected by different routes to qualification, and distinctive national school curricula and assessment frameworks.

The countries of the celtic fringe have not pursued the Anglo-American model of 'disruptive reforms' (PIEN 2012, 5) through experimentation, choice and competition to the same extent as England. Consensual and consociational political systems are arguably more consultative. The continued existence of potential veto players - such as Teaching Councils, empowered local authorities, churches and strong teacher unions - coupled with the symbolism of distinctive educational traditions, mean that devolved policy communities have some capacity to resist or absorb travelling policy regimes, producing uneven patterns of change. In the three devolved contexts there is political capital in searching for policy ideas beyond those advanced by Ministers at Westminster. Decision makers increasingly look to European (especially Nordic) models of public service provision and supra-national agencies for evidence for policy, especially the OECD. While policy capacity has grown in the period postdevolution, the small number of civil service policy professionals working within the 
devolved administrations increases the prescience of external advice. From 2010, the 'constrained divergence' (Raffe and Byrne 2005, 1) that was characteristic of education policy making in the early post-devolution period has given way to 'accelerated divergence' (Hodgson and Spours 2016, 516).

\section{The politics of expertise}

The externalisation of policy advice through the use of consultants is one expression of the pursuit of legitimacy for government policy. Invited reviewers are members of an epistemic community, defined by Haas $(1992,3)$ as, 'a network of professionals with recognised expertise and competence in a particular domain and an authoritative claim to policy-relevant knowledge within that domain or issue area'. Government appointed experts occupy a privileged position, commanding the dual warrant of peer esteem and state resource (Dunlop, 2014). Consultants are 'approved knowers' (Gunter and Forrester 2009, 507): individuals appointed in a personal capacity that are brought into the policy process on contractual arrangements to diagnose problems, enhance problem definition, and suggest policy alternatives by providing options and recommendations. Certain forms of expertise - associated with the production of decision-useful or actionable knowledge - are privileged within established power-knowledge formations. The selection of experts, the composition of advisory groups and the terms of reference offered influence the advice that is provided (Ambrus et al. 2014). Advisory roles in applied policy fields require a combination of expert knowledge and professional capacity. As experts are commissioned to respond to policy dilemmas rather than researcher-generated problems, they are required to link specialised knowledge with the practices, institutions and experiences of diverse actors within the professional field.

The attribution of expertise is itself social and dynamic. The elite status of individuals changes over time and between networks and locations (Harvey, 2011). 
Indeed, expertise is made through processes of consultation and deliberation (Jasanoff, 2003). Pfister and Horvath $(2014,311)$ note that, 'expertise is constructed in dialogical processes within expert communities and with their specific audiences of, for instance, bureaucrats, politicians, the media, or broader publics'. Issue expertise is ascribed to those with credibility derived from membership of key bodies, academic credentials, sustained issue involvement, leadership skills and a record of accomplishment in providing policy advice (in regard to effecting change).

The pool of issue experts on teacher education policy in the UK is relatively small with a number of repeat players invited to act as consultants in different places at different times. May et al. $(2016,200)$ describe how, 'Hyper-experts gain a reputation as the go-to experts for issues related to specific policies over time because of their repeated appearances, further strengthening their role in defining and informing policymaking'. The prevalence of influential and trusted repeat players may contribute to convergence or consistency in policy recommendations, if not policy making. Reviews are not binding. The closely linked education systems of the UK mean that nomadic 'hyper-experts' occupy the dual role of inside-outsiders as they move between time-limited commissions and operate at different scales - local, national and international. During a career in education 'hyper-experts' typically work across government, professional and academic boundaries; shifting from nested expert advice, to temporary secondment, to for-hire consultant at different stages of the career cycle.

\section{Methods}

To investigate the role of expert advisers seven key actors recruited to lead national reviews of teacher education in Northern Ireland, Scotland and Wales (2010-2015) were approached to participate in this study; this represents the total relevant population. No 
response was obtained from one prospective participant. Particular care was taken to acknowledge the limits to anonymity given the small sample size, the visibility of the respective review process and the public availability of the review reports (BERA, 2011). The return of verbatim transcripts for accuracy checks, on request, was agreed in advance with all participants. Pre-interview preparation involved document analysis of the corpus of data generated through the commissioned review process and biographical profiling of participants. It should be noted that this study is restricted to the reported perspectives of expert advisers. The inclusion of acting civil servants, whilst potentially very valuable, was precluded due to confidentiality codes.

Flexibility was offered in terms of the mode of interview to accommodate the preferences, availability and diverse national locations of the interviewees and members of the research team. Six retrospective interviews of between sixty and ninety minutes duration were conducted between May and June 2016. Two of the six interviewees came from involvement in the academic community in England. Two interviews were conducted via telephone; one via internet video call, and three face-to-face at the interviewee's chosen venue. Different modes did not produce discernible differences in the quality of interaction, substantive content, or duration (Irvine et al. 2012).

Elite research participants are skilled communicators, and policy advisers drawn from the academic community are attuned to research as a social practice. In approaching the interview encounter as source of shared meaning-making and knowledge construction, the researchers were sensitive to the influence of their own positionality. In contrast to literature that stresses asymmetries of power, due to the researcher's control over recordings and analysis (Kvale and Brinkman, 2014), in this study the interviewers are less senior academic colleagues within a common 
professional field. All participants thus navigated between insider-outsider positions; a process described by Plesner $(2011,471)$ as 'studying sideways'.

The interview guide was structured to scaffold conversation in relation to three stages: (i) coming into the review process; (ii) undertaking the review; and (iii) the outcomes of the review process (Appendix 1). Open questions, with prompts and probes, were used to allow interviewees to articulate their views. Transcription of digital audio files was completed using professional transcription services. Transcripts were checked against the audio record to clarify areas of ambiguity, word confusion or missing data.

Initially each researcher worked independently on one transcript (line-by-line coding and annotation) followed by a team meeting to discuss interpretation of text segments. Subsequently a draft code frame was constructed, shared and amended to improve code definitions and reduce overlapping meanings. An NVivo project was created to systematise the analysis process and support the group coding process.

In addition, interview sources were checked against other sources of evidence published documents, media reports, and official records. Triangulation of multiple data sources by different researchers was employed to assess the warrant of claims. Potential bias through interviewee memory lapse, selective memory or post hoc rationalisation was minimised via careful process tracing through document and digital archive sources.

\section{Results and Discussion}

This section presents three key interrelated and cross-cutting themes: (1) the localisation of international good practice; (2) the significance of time and temporality in local policy deliberation; and (3) the autonomy-engagement dynamic in government commissioned reviews of public policy fields. Using the analytical concept of 
translation, the analysis is attentive to time, space and positionality in making sense of the activities of expert advisers in nationally anchored and outward-facing review processes.

\section{The localisation of international good practice}

According to the rational choice model of political advice, expert input is sought to reduce complexity and increase the legitimacy of policy choices (MacDonald, 2003). Review reports produced by national advisers drew on multiple exemplars of highperforming systems of teacher education selected from the diverse geo-political contexts of Finland, Shanghai-China, Singapore, Taiwan, areas of Canada and the United States. Features of success were extracted from a small number of frequently cited consultancy reports (Barber and Mourshed 2007, 2009; Barber, Whelan and Clark, 2010); as well as international and country OECD reports (Schleicher, 2012; OECD 2007, 2010, 2014a, 2014b) and reports addressing teacher education from the European Commission $(2007,2013)$.

By repeating a selection of totemic sources a number of assumptions within a global narrative or meta-discourse remain unchallenged and are reconstituted. These texts convey the assumption that high measures of teacher effectiveness are linked with highly effective systems for teacher development. Judgments about teacher quality are inferred from the results of international assessments of student performance. In drawing on these sources, the national review reports reproduced a global policy script about the features of effective teacher education programmes (Ingvarson et al., 2014; Darling-Hammond, 2006). In this way, rapid evidence review can result in decontextualised and de-politicised advocacy of global good practices without addressing in sufficient detail how the problem of teacher quality has been posed; or considering 
the possible limitations of using international assessment data as a proxy measure for educational standards or teacher quality.

The formal terms of reference for the national reviews (which varied in scale and duration but did not exceed eleven months) were informed by a pragmatic public management perspective. In each case, commissioners required that the features of good practice internationally were subject to translation to support local knowledge use. In Northern Ireland, attention was directed towards, 'quality, efficiency, continued support for the existing diversity of provision, and with regard to each option's potential ease of implementation' (DEL 2014, 46). In Wales, options presented to the Minister were evaluated in terms of their potential contribution to raising the quality of the system, their value for money and their achievability. In Scotland, the remit of the review was more wide ranging and emphasised 'openness', 'evidence' and 'inclusivity' (Donaldson 2011, 106). Commissioned policy advisers demonstrated 'transgressive competence' (Nowotny $2000,5)$ in processes of filtering and adaption. As Nowotny $(2000,16)$ notes,

Narratives of expertise must respond to issues and questions which are never only scientific and technical... They have to develop an acute sense for different kinds of concerns, defences, wishes or anxieties and the experience that a mixed audience may have.

In reviewing evidence and distilling messages for diverse policy and practitioner audiences, advisers blended travelling policy ideas with evidence from domestic regulatory regimes including the school inspectorate, employment data from Teaching Councils, as well as representation from sector bodies such as the Universities Council for the Education of Teachers Northern Ireland and Wales. Through local 're-assemblies' or 'bundles of policy ideas' (Ball 2016, 550, 553) advisers constructed a narrative adapted to local commissioners' demands for system improvement. 
At a programmatic level, the review reports present good practice aspirations distilled from exemplary programmes: assessment based on professional standards, connected clinical practice, investment in early professional learning (mentored induction) and continuing development. Clinical practice models of professional preparation and initiatives to establish hub teaching schools, or training schools, were received positively across the reviews. The selection of examples of success includes the Finnish system of university training, the Melbourne Graduate School of Education clinical teaching model, the University of Oxford Education Deanery. The reports draw attention to teacher development beyond qualification to teach by citing the Santa Cruz/Silicon Valley New Teacher Programme and the Carnegie Corporation's Teachers for a New Era initiative. The desirability of master's level development opportunities for teachers is presented as in accord with the international trend advanced by the European Union's Bologna process. Connections between initial qualification and the continuing development of the teacher workforce are made with reference to national reviews of Teacher Standards in Hong Kong, New Zealand and Australia.

Advisers emerge as active agents in the diffusion of a re-invigorated professionalism that reasserts (and in doing so also defends) a conceptualisation of teaching as a complex intellectual activity. Panel membership is not demographically diverse and the selected independent experts draw on the common intellectual resources of a broad but coherent, professionally-oriented field. The professional project is not static but perpetually under (re-)construction. The espoused variant of professionalism deployed across the reviews reaches back to notions of 'extended professionalism' (Hoyle, 1974) through to more recent articulations of research-informed professionalism (BERA-RSA, 2014). This blend of past and present good-case exemplars is future-focused, drawing on professional as well as managerial (vertical) forms of accountability, but falls short of a 
radical departure towards (horizontal) emancipatory forms of democratic teacher education (as espoused, for example, by the Teacher Education Exchange, 2017; or Kretchmar and Zeichner, 2016).

There is a high degree of cross-referencing with adviser participation in earlier reform efforts and formal reviews in the UK and Ireland, and co-citation of adviser activity. Half of the adviser pool were engaged in consultancy activity across multiple sites and organisations, and were accustomed to operating between different scales organisational, regional, national and international. These indicators suggest a 'shared epistemic sensibility' (Ball 2016, 553) among the repeat players engaged in reviews of teacher education commissioned by the three smaller countries of the UK:

\footnotetext{
We all came out of the same tradition of teacher education as being a serious activity, a knowledge-based activity, an activity that to be practised well requires access to research findings, professional work that is illuminated by research; all members of the panel shared that approach; they were united in that vision of teacher education.
}

The work would be intellectually defensive with the slogan, which we put together, where we have reformed teacher education that is both rigorously practical and intellectually challenging at the same time.

Advisers worked with the tenets of 'occupational professionalism' (Evetts, 2009) derived from earlier regimes and career experiences in the UK, blended with emergent forms of clinical preparation associated with the most recent 'practicum turn' in teacher education internationally (Mattsson et al., 2011). Awareness was shown of the political dynamics of policy attraction. While the features of effective teacher education programmes were read from a travelling policy script, mobile ideas were re-worked as a guide to action fitted to specific local contexts. 


\section{Time and temporality in local policy deliberation}

Advisory work is implicated in each temporal mode: past, present and future. Time features in the advisory process in a number of ways: (1) problem definition (timeliness and construction of a problematic earlier past); (2) the compressed sequence of the advisory process (duration of the commission); (3) awareness of the legacy of previous regimes in engagement with stakeholders (memory); (4) awareness of the cyclical nature of the policy process, especially the electoral cycle (time window/opportunity); and, (5) awareness of a need for temporal alignment between related developments that may constrain or support the intended direction of travel in the future. Pollitt has argued $(2008,9)$ that the past is often approached in public policy making, 'not as a resource, or a potential ally, in the change process, but principally as a problem'. In preparing options for the future, advisers reported a need to engage with a past and present deemed to be problematic. Advisers enter the policy process at a particular juncture, following problem identification and initial definition, and an agreement among decision makers to seek intelligence. Once appointed, advisers engaged in the politics of framing, attending to some dimensions of the problem above others. Within the constraints of a time-limited commission, advisers expressed a need to engage in pragmatic rapid evidence assessment while demonstrating sensitivity to earlier regimes and values. In uncertain times there is a tendency towards 'fast policy' (Peck, 2002) based on demands for urgent action and nimble responses. The repeat players taking up advisory roles in Scotland, Northern Ireland and Wales were aware from previous experience that the time window for commissioned reviews to influence policy is finite, and assessment of policy outcomes is often premature. In doing advisory work, advisors used their judgement to assess what was opportune at particular junctures. 
For some advisers, the review process was approached as, 'a way of breaking the log-jam and helping to push things forward'. Indeed, a commitment to positive change was cited as a common motivation in accepting the commission. However, in formulating options, advisers acknowledged that they were engaged in the art of the possible:

We were all well aware that it's no good coming in and just saying it would be a good idea if you did $\mathrm{x}, \mathrm{y}$ and $\mathrm{z}$. We were all well aware of realpolitik, and the need to work with the stakeholders to understand their perspectives, to respect their perspectives, and to be as political with a small ' $p$ ' as the context required.

There were values and ways of seeing the world that had to be accommodated, that wouldn't accommodate to a rationalist model.

Each review was commissioned at a time of contracting public resource. Advisers acknowledged the tensions between a need for immediate economic efficiency gains and investment in the longer-term gains accrued from improvements in teaching quality across the career course. Deliberation in one sector of education was adversely affected by the scale of economies across school and university education, and the wider public sector:

We seemed to hit a maelstrom...We didn't hit a very favourable climate... There were cutbacks all over the place and when you are in that kind of position developments like this tend to get side-lined. In the short-term it might seem economic to do that, but if you are going to build really good co-ordinated collaborative work it is going to take money too.

Often it's going to be an incremental journey, start small and maybe change it in time, which is not what Ministers want, of course... Education research doesn't necessarily provide the answers but it really does, and can, shape the way people think about problems. In this case, I think we succeeded in getting the research into the discussion about what they should do in the future. They may make the wrong decisions, but at least they're much better informed now than they were. 
Where some advisers were engaged for a single time limited commission, others sought or were subsequently invited to sustain their involvement. In moving from advice for policy to policy steering, these advisers adopted the role of 'policy entrepreneur' (Kingdon, 1995) or 'policy activist' (Yeatman, 1998). This found expression in attempts to align the reform of the system of teacher education with reforms to the school curriculum and assessment framework. The degree to which this was achievable reflected the range and influence of veto players (counter forces), and the degree of coherence and continuity at senior levels of government; as well as the professional standing and intellectual resources of the policy advocate.

One adviser spoke of the importance of coalition building to increase the potential impact of the report. This was particularly important where there was a perception that experts 'came with baggage' or 'with an agenda'. Knowledge of the local policy context, the legacy of previous regimes and network relations achieved through recursive engagement could support bridge building or act as a barrier to participant engagement. The review process itself could be used to build an 'advocacy coalition' (Sabatier, 1999) to avoid inertia, particularly during the period immediately before a parliamentary election. An adviser acknowledged that, 'if it had been caught up in the hurly-burly of an election it would have sunk without trace'. Another indicated that:

The report was published four months in advance of the general election. When I met with the spokespersons of the other political parties I tried to impress on them that this was far too important to play politics with. Don't attack the report because you think you're going to have a go at the Minister. You attack the report because you don't like the report, not because it's going to be part of the run up to an election.

The final theme in this section addresses the politics of doing advisory work. Here we 
bring agency to the foreground and highlight processes of contestation that are often under-acknowledged in uni-directional approaches to policy lending or transfer.

\section{Autonomy-engagement dynamic in government commissioned reviews}

At a micro level, advisory work is subject to the political strategies, interests and aims of commissioners and stakeholders. Advisers undertaking national reviews were aware of the political nature of their engagement, and the potential for instrumental and symbolic use of consultative activities and policy advice. Expert reviews may be commissioned for a range of purposes - to consider policy alternatives for radical change, the pursuit of (hyper-)incremental change in times of uncertainty, to create a perception of manageability, or to advance a preferred solution to a pre-defined problem. In different contexts, advisers reported being able to exert varying degrees of influence over the terms of reference and execution of the review; this ranged from leadership in contexts that were more amenable to challenge, through to accommodation in more constrained contexts. For instance,

I was very clear that this would be my review and I would say whatever I thought needed to be said, and that it would not require the approval of Ministers before publication. This was an independent review on my part. I got agreement with officials and Ministers that there were no givens. There were no no-go areas in terms of thinking. If the logic of the evidence I was getting, in the research I was undertaking, took me in a direction that was becoming quite radical, well that's where it has to go. Whether they quite realised what that meant I'm not sure, but they agreed with it, and that was written into the terms of reference.

In the nicest possible way, we were set up and being used, it seemed to me. It was just obvious. What we really had to do was legitimize that.

Having negotiated or accepted the scope of their remit, advisers faced the challenge of appearing to retain a high degree of autonomy in the course of their deliberation. 
Advisers needed to mediate expectations from central government, including handling civil service interaction. All interviewees reported that civil servants 'kept a close tab' on the activities, although relations were generally described as 'very business-like and co-operative', 'helpful, supportive and very cordial'. While civil servants acted as gatekeepers, supporting various levels of access to practitioners through a formal consultation process, advisers sought to retain control over the format and authorship of the final report.

The question of the ownership and authorship of the report was vitally important, and I think I made sure that the report was ours and wasn't owned by the civil service.

The reviews varied in the extent to which advisers sought, and were able, to exercise personal agency in regard to interpreting the remit and extending the terms of reference to encourage new thinking. For some this entailed selection of support staff, expanding the number of staff appointed to undertake work, producing an uncommissioned (and uncosted) written report to communicate recommendations, using public lecture opportunities to mobilise support and to press an agenda for change with senior stakeholders and the wider education community. While reports were commissioned for Ministers, the reviews conducted by advisers adopting the role of policy advocate were authored with multiple audiences in mind, especially with regard to possibilities for future enactment.

All of the reviews involved a degree of formal consultation with interested parties. There was consensus on the desirability of stakeholder engagement from a management and ethical perspective. Principles of openness and representativeness require a degree of interplay between experts and interested parties. The degree of inclusivity reflected the time and resource available, and the established norms governing policy formation 
in each jurisdiction. In each case the review process was presented as consultative, to build credibility and garner support for proposals from the education community; and reflected advisers' positioning of teachers (and teacher educators) as key agents of change:

It was a fundamental tenet of the review that it would be as participatory as I could possibly make it. My very firm belief was that the extent to which the result of the review would strike a chord with all the various stakeholders would be heavily influenced by the extent to which everyone who felt that they had something to say, had had the chance to say it.

The teaching profession is the actor in the policy process.

Where advisers exhibited the characteristics of policy entrepreneurs, engagement with expert stakeholders was pursued for the purposes of social learning, as well as social license. Policy recommendations were tested for feasibility and stakeholder receptiveness in the course of advisers' engagement with professionals at different levels: sector regulatory bodies, university programmes and school partners. The formulation of recommendations was assisted by the back and forth exchange and mediation of policy knowledge. For instance,

The method of the review was already part of the dissemination of the review. In discussions as the review developed I would risk with people, begin to play to them some of the things that were emerging, and ask them how that rang true. I was testing different themes that were emerging from the review, and getting reactions to that. So, there was a constant iterative process of refinement and engagement as the process went forward.

The process of stakeholder engagement was acknowledged as inherently political. Engagement elicited power plays by organised sectional interests often seeking to defend the status quo and/or holding negative perceptions of previous reform efforts. It 
is often noted that strong policy communities are associated with policy continuity rather than change (Marsh and Rhodes, 1992). Social capital can be conservative as well as a resource for change. Throughout the review process advisers sought, 'to resist being browbeaten by any one point of view' although some interest groups 'pushed us quite hard'. Resilience, tenacity and sensitivity to context were important attributes. One adviser described the process as “quite fraught...they're not called stake-holders for nothing'. Others reported a minority of instances of inauthentic or 'protective and defensive' engagement that contributed to an 'impasse', a 'siege mentality' in which the establishment of a review itself was regarded as 'a plot by the Minister' to pursue a predetermined agenda. While in each case the review reports were publicly welcomed as constructive by collective voices in the education community, some disquiet was channelled in private. One adviser commented on the 'quite bitter resentment that has been expressed to me personally' from stakeholders.

Some stakeholders were galvanising support to try and both make a case to us, but also undermine the legitimacy of the review so that it wouldn't go anywhere.

You're not going to make any progress if one powerful group have been advised, and they see it as their duty, to oppose all options.

I think they saw us as a tool of somebody, some political agenda...It wasn't so much a lack of co-operation, but it was just, a kind of closed-ness of perspective.

Some felt that we were being manoeuvred, we were political stool pigeons...that this was political and we were being wheeled in to do a political job. That wasn't our experience, but that was the attitude we met.

In negotiating contested terrain, the advisers drew on intellectual resources and professional skills acquired in lengthy careers in higher education management. It was emphasised that 'political awareness is very important' in building relations of trust and 
cooperation. The mode of engagement - how, when and why advisers engaged in particular consultative activities - reflected their understanding of prevailing local conditions and the history of earlier policy regimes. Advisory work from the perspective of the participants detailed above entailed deliberate, iterative activity and an attempt to build relationships within challenging time constraints and uneven power relations.

\section{Conclusion}

This article has reported the experiences of expert advisers commissioned to conduct national reviews of teacher education of the smaller nations of the United Kingdom. The study illustrates how advisers act as 'conduits of policy mobility' (Ball 2016, 557), 'transfer agents' (Stone, 2004) who participate in the translation of globally mobile ideas through networks of 'best practice peers' (Larner and Le Heron 2004, 215). This analysis reinforces McCann and Ward's $(2013,10)$ assertion that, "the spaces and times of travel are not 'dead' or unimportant but should be taken seriously as playing a role in shaping policy knowledge". This small-scale study of repeat players provides vicarious insight into the 'globalising microspaces' (Larner and Le Heron 2002, 765) or policy making locales where travelling ideas are tested and re-made. These include the procedures and places of formal consultation and public engagement: meeting rooms, electronic forums, deliberation spaces within professional communities and the wider media. The analysis presented here points to the continuing significance of local political strategies in shaping policy choices and prospects for enactment.

The study findings highlight some of the limitations of the policy transfer approach advanced in UK political science (Dolowitz and Marsh, 1996) to education policy studies. While drawing on a global policy script of effective teacher education, the locally produced recommendations generated through review processes in the three closely linked countries cannot be explained in terms of top-down, outside-in transfer. 
Contextual influences on national review processes identified in this study included: the timeliness of the review; the economic climate during the review (pressures for rationalisation and efficiency gains vis-a-vis strategic investment in teacher development); the knowledge, skills, commitment and aspirations (or policy activism) of appointed advisers; the receptiveness of stakeholders (e.g. 'protective and defensive' engagement by multiple and/or influential veto players within and beyond the teacher education community); and the degree of cross-party support, and continuity over time between Government Departments/Divisions.

An assemblage perspective is useful in examining how those engaged in advocacy and resistance deploy 'local tactics of education, persuasion, inducement, management, incitement, motivation and encouragement' (Rose and Miller 1992, 175). Practices of assembly involve constant political work with different effects. From this perspective, the realisation, partial or non-transfer of extra-local policy regimes is not a 'failure' to heed expert advice but an outcome of translation. As Stone $(2017,11)$ observes, 'divergence is expected: policy translation - characterised by fluid multiactor processes of interpretation, mutation and assemblage - is the constant reality'. While there are strong drivers towards upward convergence, uneven responses remain possible. An assemblage perspective has much to offer in understanding the contribution of expert advisers to open-ended or 'restless reform' (Peck 2002, 331). The analysis presented here indicates that further work might usefully be directed towards 'people, places and moments' (Prince 2010, 170) in enhancing our understanding of how policy ideas move and are changed by travel.

\section{References}

Alexiadou, N. \& Jones, K. 2001.’Travelling Policy/Local Spaces,” Paper presented at the Congres Marx International 111 Le Capitale et L'Humanite University of Paris X, 2629 September. 
Ambrus, M., Arts, K., Hey, E., Raulus, H. eds. 2014. The Role of 'Experts' in International and European Decision-Making Processes. Cambridge: Cambridge University Press.

Ball, S.J. 2016. "Following policy: networks, network ethnography and education policy mobilities," Journal of Education Policy, 31(5), 549-566.

Barber, M. \& Mourshed, M. 2007. How the World's Best-Performing School Systems Come Out on Top. London: McKinsey \& Company.

Barber, M. \& Mourshed, M. 2009. Shaping the Future: How Good Education Systems Can Become Great in the Decade Ahead. London: McKinsey \& Company.

Barber, M., Whelan, F. \& Clark, M. 2010. Capturing the leadership premium: How the world's top school systems are building leadership capacity for the future. London: McKinsey \& Company.

Beauchamp, G., Clarke, L., Hulme, M. \& Murray, J. 2015. "Teacher Education in the UK Post Devolution: Convergences and Divergences," Oxford Review of Education, 41(2), 154170.

Beck, U. 2006. Cosmopolitan Vision. Cambridge: Polity Press.

BERA 2011. Ethical Guidelines for Educational Research. Accessed 19 January 2019 https://www.bera.ac.uk/researchers-resources/publications/bera-ethical-guidelines-foreducational-research-2011

BERA-RSA 2014. Research and the Teaching Profession: Building the Capacity for a SelfImproving Education System. Accessed 19 January 2019 https://www.bera.ac.uk/project/research-and-teacher-education

Cochran-Smith, M., Stern, R., Sánchez, J.G., Miller, A., Keefe, E.S., Fernández, M.B., Chang, W., Carney, M.C., Burton, S. \& Baker, M. 2016. Holding Teacher Preparation Accountable: A Review of Claims and Evidence. Boulder, CO: National Education Policy Center.

Collier, S.J. and Ong, A. 2005. "Global assemblages, anthropological problems". In Global Assemblages: Technology, Politics and Ethics as Anthropological Problems, edited by Ong, A. \& Collier, S.J., 3-21. London: Blackwell.

Clarke, J. 2012. "Historical amnesia: linking past, present and future in politics and policy," Research, Policy and Planning, 29(3), 153-160.

Clarke, J., Bainton, D., Lendvai, N. \& Stubbs, P. 2015. Making Policy Move. Towards a Politics of Translation and Assemblage. Bristol: Policy Press.

Craft, J. \& Howlett, M. 2012. "Policy Formulation, Governance Shifts and Policy Influence: Location and Content in Policy Advisory Systems," Journal of Public Policy 32(2), 7998.

Darling-Hammond, L. 2006. Powerful Teacher Education: Lessons from exemplary programs. San Francisco: Jossey-Bass.

Davies, P., Connolly, M., Nelson, J., Hulme, M., Kirkman, J., Greenway, C. \& Hadfield, M. 2016. "'Letting the right one in': Provider contexts for recruitment to initial teacher education in the United Kingdom," Teaching and Teacher Education, 60, 291-302.

Dolowitz, D. P. \& Marsh, D. 1996. "Who Learns What From Whom? A Review of the Policy Transfer Literature." Political Studies, 44(2): 343-57.

Donaldson, G. 2011. Teaching Scotland's future: A report of the review of teacher education in Scotland. Edinburgh: Scottish Government. 
Dunlop, C. A. 2014. "The possible experts: how epistemic communities negotiate barriers to knowledge use in ecosystems services policy" Environment and Planning $C$ : Government and Policy, 32(2), 208-228.

European Commission 2007. Improving the Quality of Teacher Education. Brussels: European Commission

European Commission 2013. Supporting Teacher Educators for Better Learning Outcomes. Brussels: European Commission.

Evetts, J. 2009. “The management of professionalism: a contemporary paradox”. In Changing Teacher Professionalism: International Trends, Challenges and Ways Forward, edited by S. Gewirtz, P. Mahony, I. Hextall and A. Cribb, 19-30. Routledge: London.

Furlong, J. 2015. Teaching Tomorrow's Teachers. Oxford: University of Oxford. Accessed 3 October 2017 http:/gov.wales/topics/educationandskills/publications/wagreviews/teachingtomorrows-teachers/?lang=en

Goldhaber, D. 2018. "Evidence-Based Teacher Preparation: Policy Context and What We Know". Journal of Teacher Education. https://doi.org/10.1177/0022487118800712

Grek, S. 2013. "Expert Moves: International Comparative Testing and the Rise of Expertocracy.” Journal of Education Policy, 28(5), 695-709.

Gunter, H.M. and Forrester, G. 2009. "School Leadership and Policymaking in England," Policy Studies, 31(5), 495-511.

Gunter, H., Hall, D. \& Mills, C. 2015. "Consultants, consultancy and consultocracy in education policymaking in England," Journal of Education Policy, 30(4), 518-539.

Haas, P.M. 1992. "Introduction: epistemic communities and international policy coordination," International Organization, 46 (1), 1-36.

Harvey, W.S. 2011. "Strategies for conducting elite interviews," Qualitative Research, 11(4), 431-41.

Hodgson, A. \& Spours, K. 2016. "Restrictive and expansive policy learning - challenges and strategies for knowledge exchange in upper secondary education across the four countries of the UK," Journal of Education Policy, 31(5), 511-525.

Hoyle, E. 1974. "Professionality, professionalism and control in teaching." London Educational Review, 3(2), 13-19.

Ingvarson, L., Reid, K., Buckley, S., Kleinhenz, E., Masters, G., Rowley, G. 2014. Best Practice Teacher Education Programs and Australia's Own Programs. Canberra: Department of Education.

Irvine, A., Drew, P. \& Sainsbury, R. 2012. ““Am I not answering your questions properly?’ Clarification, adequacy and responsiveness in semi-structured telephone and face-toface interviews," Qualitative Research, 13(1), 87-106.

Jasanoff, S. 2003. "Technologies of Humility. Citizen Participation in Governing Science." Minerva, 41(3), 233-244.

Jung, A., Korinek, R. \& Straßheim, H. 2014. "Embedded expertise: a conceptual framework for reconstructing knowledge orders, their transformation and local specificities," Innovation: The European Journal of Social Science Research, 27(4), 398-419.

Kennedy, A., \& Doherty, R. 2012. "Professionalism and partnership: Panaceas for teacher education in scotland?" Journal of Education Policy, 27(6), 835-848.

Kingdon, J. W. 1995. Agendas, Alternatives, and Public Policies. New York: HarperCollins. 
Kretchmar, K. \& Zeichner, K. 2016. "Teacher prep 3.0: a vision for teacher education to impact social transformation." Journal of Education for Teaching 42,4: 417 - 433.

Kvale, S. \& Brinkman, S. 2014. InterViews: Learning the Craft of Qualitative Research Interviewing, 3rd ed., Los Angeles, CA: Sage.

Larner, W. \& Le Heron, R. 2002. "The spaces and subjects of a globalizing economy: a situated exploration of method," Environment and Planning D: Society and Space 20, 753-774.

Larner, W. \& Le Heron, R. 2004. "Governmentality, Geography and Globalising Processes: The Role of Calculative Practices." In Global Governmentality, edited by W. Larner \& Walters, W., 212-232. London: Routledge.

Lingard, B. \& Rawolle, S. 2011. "New Scalar Politics: Implications for Education Policy." Comparative Education 47(4), 1-18.

Lingard, B., Sellar, S. \& Baroutsis, A. 2015. "Researching the habitus of global policy actors in education," Cambridge Journal of Education, 45(1), 25-42.

Lovering, J. 1991. "Southbound again: The peripherilization of Britain.” In Regions, Nations and European Integration: Remaking the Celtic periphery, edited by G. Day \& G. Rees, 11-38. Cardiff: University of Wales Press.

MacDonald, P.K. 2003. "Useful Fiction or Miracle Maker: The Competing Epistemological Foundations of Rational Choice Theory". American Journal of Political Science, 97, 551-565.

Martens, K., Nagel, A., Windzio, M. and Weymann, A. eds. 2010. Transformation of Education Policy, Basingstoke: Palgrave Macmillan.

Mattsson, M., Eilertsen, T.V. \& Rorrison, D. eds. 2011. A Practicum Turn in Teacher Education. Rotterdam: Sense.

May, P.J., Koski, C. \& Stramp, N. 2016. "Issue expertise in policymaking." Journal of Public Policy, 36(2), 195-218.

McCann, E. 2008. "Expertise, Truth, and Urban Policy Mobilities: Global Circuits of Knowledge in the Development of Vancouver, Canada's 'four pillar' Drug Strategy." Environment and Planning A, 40(4), 885-904.

McCann, E. \& K. Ward. 2012. "Policy Assemblages, Mobilities and Mutations." Political Studies Review, 10(3), 325-332

McCann, E. \& Ward, K. 2013. "A multi-disciplinary approach to policy transfer research: geographies, assemblages, mobilities and mutations," Policy Studies, 34(1), 2-18.

NAO (National Audit Office) 2016. Accountability to Parliament for taxpayers' money. London: National Audit Office.

Nowotny, H. 2000. “Transgressive Competence: The Narrative of Expertise," European Journal of Social Theory. 3(1), 5-21.

OECD 2007. Quality and Equity of Schooling in Scotland. Paris: OECD.

OECD 2010. Strong Performers and Successful Reformers in Education: Lessons from PISA for the United States. Paris: OECD.

OECD 2011. Building a high quality teaching profession: Lessons from around the world, Paris: OECD.

OECD 2014a. Improving Schools in Wales: An OECD perspective. Paris: OECD.

OECD 2014b. Evaluation and Assessment in Education: Northern Ireland. Paris: OECD.

Peck, J. 2002. "Political economies of scale: fast policy, inter-scalar relations, and neo-liberal workfare," Economic Geography, 78(3) 331-360. 
Pfister, T. \& Horvath, A. 2014. "Reassessing expert knowledge and the politics of expertise," Innovation: The European Journal of Social Science Research, 27(4), 311-316.

Plesner, U. 2011. "Studying sideways: Displacing the problem of power in research interviews with sociologists and journalists." Qualitative Inquiry, 17, 471-482.

PIEN (Policy Innovators in Education Network) 2012. Who's Who in a Growing Education Reform Movement. Minneapolis: Policy Innovators In Education Network.

Pollitt, C. 2008. Time, Policy, Management: Governing with the Past. Oxford: Oxford University Press.

Prince, R. 2010. "Policy Transfer as Policy Assemblage: Making Policy for the Creative Industries in New Zealand," Environment and Planning A, 42(1), 169-86.

Raffe, D. \& Byrne, D. 2005. Policy Learning from 'Home International' Comparison CES Briefing, No. 34. Centre for Educational Sociology: University of Edinburgh, Edinburgh.

Rose, N. \& Miller, P. 1992. "Political power beyond the state: problematics of government," British Journal of Sociology, 43(2) 172-205.

Sabatier, P. ed. 1999. Theories of the Policy Process. Boulder, CO: Westview Press.

Sahlberg, P., Broadfoot, P., Coolahan, J., Furlong, J. \& Kirk, G. 2014. Aspiring to Excellence. Final report of the international review panel on the structure of initial teacher education in Northern Ireland. Belfast: DEL.

Schleicher, A. ed. 2012. Preparing Teachers and Developing School Leaders for the 21st Century: Lessons from around the world. Paris: OECD Publishing.

Seddon, T. \& Levin, J.S. 2013. eds. Educators, Professionalism and Politics. Global Transitions, National Spaces and Professional Projects. London: Routledge.

Stone, D. 2004. "Transfer agents and global networks in the "transnationalization" of policy," Journal of European Public Policy, 11(3),545-566.

Stone, D. 2017. "The Transfer of Policy Failure: Bricolage, Experimentalism and Translation." Policy and Politics, Vol 45(1), 55-70.

Tabberer, R. 2013. A Review of Initial Teacher Training in Wales. Accessed 3 October 2017 http://wales.gov.uk/docs/dcells/publications/131007-review-of-initial-teacher-trainingin-wales-en.pdf

Teacher Education Exchange, 2017. Teacher Development 3.0: How we can transform the professional education of teachers. London: Teacher Education Exchange.

Teacher Education Group, 2016. Teacher Education in Times of Change. Bristol: Policy Press.

Urry, J. 2003. Global Complexity Cambridge: Polity.

Wilsdon, J. \& Doubleday, R. 2015. Future Directions for Scientific Advice in Europe, Cambridge: Centre for Science and Policy.

World Bank, 2013. What matters most for teacher policies: A framework paper. SABER Working Paper Series, No.4. Washington, DC: World Bank Group.

Yeatman, A. ed. 1998. Activism and the Policy Process. St. Leonards: Allen Unwin. 


\section{Appendix One. Interview Guide}

\section{Coming into the review process}

Can you tell me a little about how you came to be involved in the review process?

How were you approached?

Were there a number of stages in the process?

What negotiations, if any, took place before you decided to accept the role?

Ways of working: parameters, scale, administrative support

Who did you talk to before accepting the role?

What is your understanding of why the review was commissioned?

Why was the review commissioned at that time?

What did you hope to achieve by being part of the review?

How familiar were you with teacher education in this national context?

\section{Undertaking the review}

How was the review managed?

Which areas of the review process did you have control over?

Which areas were devolved to others? Who were the others?

Did this arrangement change during the review? If so, in what ways?

Can you say a little about reporting arrangements to the commissioning body?

How frequently did you report back in the course of the review?

What methods were used? How was this agreed?

How did you communicate with stakeholders about the review? E.g.

Record of stakeholder engagement activities

Access to minutes of meetings

Access to submissions

Did you have access to everyone you wanted to talk to?

Did you meet with the expected levels of cooperation from all participants?

Did anything or anyone inhibit the review process?

In your experience, what soft skills do Advisors most require?

Was there consensus within the expert panel/Reference Group?

On most issues?

On some issues?

How did you manage any differences?

Could you say a little about the ethical issues in conducting advisory work?

What policy ideas from other jurisdictions seemed to gain traction in your review country? In your opinion, why was there receptiveness to these ideas?

Were there policy ideas from elsewhere that did not gain traction? If so, why?

\section{Outcomes from the review}

How did you decide how to present your recommendations? What considerations were uppermost in deciding how best to communicate your recommendations -

To policy makers (commissioning body)?

To the profession?

What was the influence of the local (national) context on how you developed your report? What was the influence of the local (national) context on the recommendations? How was your report received?

By government?

By the profession?

Beyond the national context?

What influence has the report had on decision makers? 
To what extent were opinions challenged or changed?

What influence has the report had on policy?

Directly

Indirectly

Short-, medium-, longer-term

Have you had further involvement with the commissioning body after formal submission of the review?

What did you learn from the review? Has this influenced your work in other national contexts? If so, how?

Looking back, is there anything that you would have done differently? 